\title{
Development and in vivo evaluation of the moisturising potential of cosmetic formulations containing Babassu (Orbignya phalerata Martius) oily extract
}

\author{
Desenvolvimento e avaliação in vivo do potencial hidratante de formulações cosméticas \\ contendo extrato oleoso de Babaçu (Orbignya phalerata Martius)
}
Italo Rennan Sousa Vieira ${ }^{1 *}$, Joaquim Silva Sales ${ }^{2}$, Cristal dos Santos Cerqueira-Coutinho ${ }^{3}$, Thauany Hell- mann $^{2}$, Bruna Fernanda Silva de Sousa², Joaquim Teixeira Lopes ${ }^{2}$, Adriana Leandro Camara ${ }^{4}$, Maria Célia Pires Costa ${ }^{2}$, Eduardo Ricci-Júnior ${ }^{3}$, Elisabete Pereira dos Santos ${ }^{3}$
${ }^{1}$ Instituto de Química, Universidade do Estado do Rio de Janeiro, Pavilhão Reitor Haroldo Lisboa da Cunha, Maracanã, 20550-900, Rio de Janeiro, Brasil
${ }^{2}$ Departamento de Química e Biologia, Universidade Estadual do Maranhão, Campus Universitário Paulo VI,65055-970, São Luís, Maranhão, Brasil
${ }^{3}$ Departamento de Medicamentos, Universidade Federal do Rio de Janeiro, Faculdade de Farmácia, Cidade Universitária, Ilha do Fundão, 21941-902, Rio de Janeiro, Brasil
${ }^{4}$ Departamento de Ciências Fisiológicas, Universidade Federal do Maranhão, Campus do Bacanga, 65085-580, São Luís, Maranhão, Brasil
Email: italorennan2010@gmail.com

\begin{abstract}
The objective of this study was to use oily extracts of the species Orbignya phalerata Martius (Babassu) from three ecological regions in Maranhão state, Brazil: Forest (BBF), Coast (BBC) and Lowlands (BBL) to develop cosmetic formulations. Formulations with $10 \mathrm{wt} \%$ of Babassu oily extracts were characterised regarding their stability for 30 days (separation of phases after centrifugation, $\mathrm{pH}$, density, viscosity and droplets size distribution) and evaluation of efficacy in vivo by cutaneous biometry. Results indicated that the formulations were physically stable and presented pseudo-plastic fluid behavior as evaluated by rheology. Concerning the in vivo efficacy assays, the formulation containing BBL increased the hydration of the volunteers'skin when compared to a formulation containing only a commercial standard moisturising ingredient, without altering the skin $\mathrm{pH}$. BBL showed to be a promising ingredient to cosmetics, behaving as an excellent moisturiser likely because it contains the highest amounts of lauric, myristic and oleic acids that present great emollient potential.
\end{abstract}

Keywords: Cosmetic formulations, cutaneous biometry, in vivo evaluation of moisturising effect, Orbignya phalerata Martius, vegetal oily extract.

\section{Resumo}

O objetivo deste estudo foi utilizar extratos oleosos da espécie Orbignya phalerata Martius (Babaçu) de três regiões ecológicas do Estado do Maranhão (Brasil): Mata dos Cocais (BBF), Litoral (BBC) e Baixada Maranhense (BBL) para desenvolver formulações cosméticas. As formulações com $10 \%$ em peso de extratos oleosos de Babaçu foram caracterizadas quanto à sua estabilidade durante 30 dias (separação de fases após centrifugação, pH, densidade, viscosidade e distribuição de tamanho das gotículas) e avaliação da eficácia in vivo por biometria cutânea. Os resultados indicaram que as formulações foram fisicamente estáveis e apresentaram comportamento de fluido pseudoplástico, avaliado por reologia. Em relação aos ensaios de eficácia in vivo, a formulação contendo BBL aumentou a hidratação da pele dos voluntários quando comparada com uma formulação contendo apenas um ingrediente hidratante padrão comercial, sem alterar o $\mathrm{pH}$ da pele. BBL mostrou ser um ingrediente promissor para cosméticos, comportando-se como um excelente hidratante, provavelmente porque contém as maiores quantidades de ácidos láurico, mirístico e oleico que apresentam grande potencial emoliente.

Palavras chave: Formulações cosméticas, biometria cutânea, avaliação in vivo do efeito hidratante, Orbignya phalerata Martius, extrato oleoso vegetal. 


\section{Introduction}

In recent years, there is a growing demand in the production of cosmetic products based on natural products, especially vegetable oils. In the cosmetic industry, vegetable oils extracted mainly from the seeds of plants and fruits are considered important raw materials for the development of ecological cosmetics. Cosmetic products based on vegetable oils help protect the skin from excessive fluid loss, allow skin respiration and assimilate sunlight (1). The oil extracted from Babassu (Orbignya phalerata Martius) coconut almonds has generated interest in the cosmetics industry, becoming a major candidate for application in cosmetic products, mainly for topical use (2-4).

Babassu is the generic name given to the oil palm trees belonging to the Palmae family that are members of the genera Orbignya and Attalea. The Babassu palm is native from Brazil and its oil is the extractive product produced most in Brazil, contributing significantly to the economy of some Brazilian states (5).

The importance of Babassu oil for cosmetics is related to its composition.It presents emollient properties and can promote skin hydration without increasing oiliness. Previous studies have shown that Babassu oil contains high quantities of triacylglycerides, such as lauric, myristic and oleic acids $(5,6)$. Approximately $82-88 \%$ of the oil is composed by saturated fatty acids and 12$18 \%$ is made up of unsaturated acids. Its fatty acid composition includes lauric (44-46\%), myristic (15-20\%), oleic $(12-18 \%)$, palmitic $(6-9 \%)$, stearic $(6 \%)$, caprylic (4.0-6.5\%), capric $(2.7-7.5 \%)$, caproic $(0.2 \%)$, and arachidic $(0.2-0.7 \%)$ acids $(7,8)$. Furthermore, it presents small amounts of phospholipids, pigments, sterols and tocopherols (5).

Babassu oil could be also used in hair care, since the lauric fatty acids and unsaponifiables replace the lipid content of the hair and also confer elasticity to hair fibers $(6,8)$. Babassu oil also presents emulsifying properties, which justifies its use in oil-in-water $(\mathrm{O} / \mathrm{W})$ emulsions. In general, fatty acids whose carbon chain range from 8 to 16 carbons behave as surfactants and have good detergent and emulsifying properties (2).

Besides the cosmetic potential, Babassu oil also demonstrated biological activities. Several studies showed that the oil of the species $O$. phalerata presented antiinflammatory activities, healing (9-11) and antithrombotic activity (12). In addition, a study was performed to evaluate the safety of unrefined Babassu oil by oral administration to hamsters. A decrease in protein passage induced by blood flow obstruction in capillary vessels of the cheek of hamsters was verified, therefore,

\section{Introdução}

Nos últimos anos, há uma demanda crescente na produção de produtos cosméticos à base de produtos naturais, especialmente de óleos vegetais. $\mathrm{Na}$ indústria cosmética, os óleos vegetais extraídos principalmente das sementes de plantas e frutas, são considerados matérias-primas importantes para o desenvolvimento de cosméticos ecológicos. Produtos cosméticos à base de óleos vegetais ajudam a proteger a pele da perda excessiva de fluidos, permitem a respiração da pele e assimilam a luz solar (1). O óleo extraído das amêndoas do coco de Babaçu (Orbignya phalerata Martius) gerou interesse na indústria cosmética, tornando-se um importante candidato para aplicação em produtos cosméticos, principalmente para uso tópico (2-4).

Babaçu é o nome genérico dado às palmeiras oleaginosas pertencentes à família Palmae que são membros dos gêneros Orbignya e Attalea. A palmeira de Babaçu é nativa do Brasil e seu óleo é o produto extrativista mais produzido no Brasil, contribuindo significativamente para a economia de alguns estados brasileiros (5).

A importância do óleo de Babaçu para cosméticos está relacionada à sua composição. Ele apresenta propriedades emolientes e pode promover a hidratação da pele sem aumentar a oleosidade. Estudos anteriores mostraram que o óleo de Babaçu apresenta altas quantidades de triacilglicerídeos, como os ácidos láurico, mirístico e oleico $(5,6)$. Aproximadamente $82-88 \%$ do óleo é composto por ácidos graxos saturados e $12-18 \%$ é composto de ácidos insaturados. A sua composição de ácidos graxos inclui ácido láurico (44-46\%), mirístico (15-20\%), oleico (12-18\%), palmítico (6-9\%), esteárico (6\%), caprílico $(4,0-6,5 \%)$, cáprico $(2,7-7,5 \%)$, caproico $(0,2 \%)$ e araquídico $(0,2-0,7 \%)(7,8)$. Além disso, apresenta pequenas quantidades de fosfolípidos, pigmentos, esteróis e tocoferóis (5).

O óleo de Babaçu pode também ser utilizado no cuidado capilar, uma vez que os ácidos graxos láuricos e os insaponificáveis substituem o conteúdo lipídico do cabelo e também conferem elasticidade às fibras capilares $(6,8)$. O óleo de Babaçu também apresenta propriedades emulsionantes, o que justifica seu uso em emulsões óleo em água (O/A). Em geral, os ácidos graxos cuja cadeia carbônica varia de 8 a 16 carbonos comportam-se como tensoativos e possuem boas propriedades detergentes e emulsionantes (2).

Além do potencial cosmético, o óleo de Babaçu também demonstrou atividades biológicas. Diversos estudos mostraram que o óleo da espécie $O$. phalerata apresentou atividades anti-inflamatória, cicatrizante (9-11) e atividade antitrombótica (12). Além disso, um estudo 
unrefined Babassu oil can be a safe source of lipids (5). However, no study regarding its moisturising potential has been reported, which motivated us to perform this study.

For cosmetic purposes, O/W emulsions are well accepted as they present an aqueous external phase with adequate light sensitivity and spreadability (13). O/W emulsions are important vehicles to the release of hydrophobic active compounds, such as vegetal oils (14). Emulsions are classified as thermodynamically unstable systems and do not form spontaneously. Emulsions require energy to be produced and the instability of an emulsion could lead to sedimentation, flocculation and ultimately phase separation due to the coalescence of the dispersed droplets $(15,16)$. Visual stability could be reached by using surfactants to lower interfacial tension between the dispersed phase (droplets) and the continuous phase (external) $(13,17)$.

Biological effects of emulsions depend mainly on their interfacial properties that are determined by surfactants, through a combination of electrostatic interactions, steric effects and mechanical forces (18). For this reason, choosing the right surfactant is extremely important to control the functional properties of emulsions, including physical stability and interactions with biological systems (19).

The aim of this work was to develop cosmetic formulations using $O$. phalerata (Babassu) oily extract from three regions of Maranhão (Brazil) and to evaluate their stability (phase separation, $\mathrm{pH}$, density, viscosity and droplets size distribution). Finally, the in vivo moisturising potential of the Lowlands Babassu oil was evaluated, since it is reported in literature (7) as the one with the highest amounts of emollient compounds.

\section{Materials and Methods}

The formulations were prepared using three oily extracts from $O$. phalerata, collected in different ecological regions of Maranhão state, Brazil: Forest (BBF), Coast (BBC) and Lowlands (BBL). The O. phalerata oily extracts were obtained by Babassu coconut breakers via an artisanal process which consists of heating the kernels for lipid extraction (20).

In addition, other materials were used in the preparation foi realizado para avaliar a segurança do óleo de Babaçu não refinado por administração oral ahamsters. Foi verificada uma diminuição na passagem de proteínas, induzida pela obstrução do fluxo sanguíneo em vasos capilares da bochecha dos hamsters, portanto, o óleo de Babaçu não refinado pode ser uma fonte segura de lipídeos (5).No entanto, não foi relatado nenhum estudo sobre seu potencial hidratante, o que nos motivou a realizar este estudo.

Para fins cosméticos, as emulsões O/A são bem aceitas, uma vez que apresentam uma fase aquosa externa com boa sensibilidade à luz e espalhamento (13). As emulsões O/A são veículos importantes para a liberação de compostos ativos hidrofóbicos, tais como óleos vegetais (14). As emulsões são classificadas como sistemas termodinamicamente instáveis e não se formam espontaneamente. As emulsões requerem energia para serem produzidas e a instabilidade de uma emulsão pode levar à sedimentação, floculação e finalmente separação de fases devido à coalescência das gotículas dispersas $(15,16)$. A estabilidade visual pode ser alcançada usando surfactantes para diminuir a tensão interfacial entre a fase dispersa (gotículas) e a fase contínua (externa) $(13,17)$.

Os efeitos biológicos das emulsões dependem principalmente das propriedades interfaciais que são determinadas por surfactantes, através de uma combinação de interações eletrostáticas, efeitos estéricos e forças mecânicas (18). Por esta razão, a escolha do surfactante adequado é extremamente importante para controlar as propriedades funcionais das emulsões, incluindo a estabilidade física e as interações com sistemas biológicos (19).

O objetivo deste trabalho foi desenvolver formulações cosméticas utilizando extrato oleoso de $O$. phalerata (Babaçu) de três regiões do Estado do Maranhão (Brasil) e avaliar sua estabilidade (separação de fases, $\mathrm{pH}$, densidade, viscosidade e distribuição de tamanho de gotículas). Finalmente, avaliou-se o potencial de hidratação in vivo do óleo de Babaçu da Baixada Maranhense, uma vez que é relatado na literatura (7) como aquele com as maiores quantidades de compostos emolientes.

\section{Materiais e Métodos}

As formulações foram preparadas utilizando três extratos oleosos de $O$. phalerata, coletados em diferentes regiões ecológicas do Estado do Maranhão (Brasil): Mata dos Cocais (BBF), Litoral (BBC) e Baixada Maranhense (BBL). Os extratos oleosos de O. phalerata foram obtidos por produtores de coco Babaçu por meio de um processo artesanal que consiste em aquecer as amêndoas para extração dos lipídeos (20). 
of the formulations: Hidraskin $\AA$ (a standard moisturising ingredient; a mixture of sodium lactate, glycerin and glycols),cetostearyl alcohol ethoxylate, glyceryl monostearate and butylated hydroxytoluene (BHT) (all purchased from Mapric, Brazil); a blend of phenoxyethanol and methylisothiazolinone, ammonium Acryloyldimethyltaurate/VP copolymer and ethylenediaminotetracetic acid (EDTA-Na) (all purchased from PharmaSpecial, Brazil); glycerin and imidazolidinyl urea (both purchased from Fagron, Brazil).

\section{Preparation of the formulations}

The formulations were prepared by pouring the ingredients from the oily phase, previously homogenized at $80^{\circ} \mathrm{C}$ into the aqueous phase at the same temperature (Ta-
Além disso, foram utilizados outros materiais para a preparação das formulações: Hidraskin ${ }^{\circledR}$ (um ingrediente hidratante padrão, uma mistura de lactato de sódio, glicerina e glicóis), álcool cetoestearílico etoxilato, monoestearato de glicerila e hidroxitolueno butilado (BHT) (Adquirido da Mapric, Brasil); Uma mistura de fenoxietanol e metilisotiazolinona, copolímero de amônio acrilo-dimetiltaurato/VP e ácido etilenodiaminotetracético (EDTA-Na) (Todos adquiridos da PharmaSpecial, Brasil); Glicerina e imidazolidinil ureia (Ambos adquiridos de Fagron, Brasil).

\section{Preparação das formulações}

As formulações foram preparadas vertendo os ingredientes da fase oleosa, previamente homogeneizados a $80^{\circ} \mathrm{C}$, na fase aquosa na mesma temperatura (Tabela 1). As for-

Table 1/ Tabela 1 - Components of the formulations containing Babassu oily extract Componentes das formulações contendo extrato oleoso de Babaçu

\begin{tabular}{|c|c|c|c|c|c|c|}
\hline \multirow{2}{*}{ Ingredient/Ingrediente } & \multicolumn{6}{|c|}{ Formulations/Formulações } \\
\hline & $\begin{array}{c}\text { F1 } \\
(w t \%)\end{array}$ & $\begin{array}{c}\text { F2 } \\
(w t \%)\end{array}$ & $\begin{array}{c}\text { F3 } \\
(w t \%)\end{array}$ & $\begin{array}{c}\text { F4 } \\
(w t \%)\end{array}$ & $\begin{array}{c}\text { F5 } \\
(w t \%)\end{array}$ & $\begin{array}{c}\text { F6 } \\
(w t \%)\end{array}$ \\
\hline \multicolumn{7}{|c|}{ Oil phase/Fase oleosa } \\
\hline $\begin{array}{l}\text { Cetostearyl alcohol } \\
\text { ethoxylate/ } \\
\text { Álcool cetoestearílico } \\
\text { etoxilado }\end{array}$ & 3.00 & 3.00 & 3.00 & 3.00 & 3.00 & 3.00 \\
\hline $\begin{array}{l}\text { Glyceryl monostearate/ } \\
\text { Monoestearato de glicerila }\end{array}$ & 5.00 & 5.00 & 5.00 & 5.00 & 5.00 & 5.00 \\
\hline BHT & 0.05 & 0.05 & 0.05 & 0.05 & 0.05 & 0.05 \\
\hline $\begin{array}{l}\text { Phenoxyethanol/methylisothi } \\
\text { azolinone / } \\
\text { Fenoxietanol/ } \\
\text { metilisotiazolinona }\end{array}$ & 0.20 & 0.20 & 0.20 & 0.20 & 0.20 & 0.20 \\
\hline $\begin{array}{l}\text { O. phalerata oily extract } \\
\text { (Babassu)/ } \\
\text { Extrato oleoso de } O \text {. } \\
\text { phalerata (Babaçu) }\end{array}$ & $\begin{array}{c}10.0 \\
(\mathrm{BBF})\end{array}$ & $\begin{array}{c}10.0 \\
(\mathrm{BBC})\end{array}$ & $\begin{array}{c}10.0 \\
(\mathrm{BBL})\end{array}$ & $\begin{array}{c}10.0 \\
(\mathrm{BBL})\end{array}$ & --- & --- \\
\hline
\end{tabular}

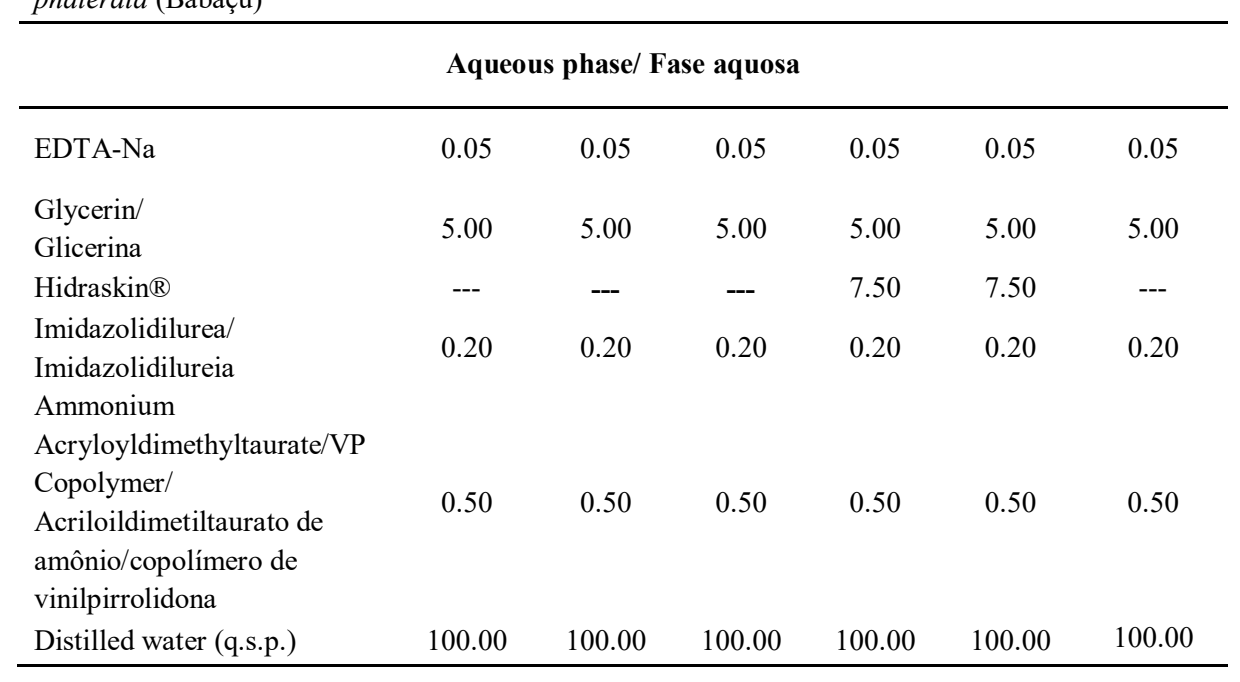


ble 1). The formulations were mechanically stirred until complete homogenization at $1200 \mathrm{rpm}$ for 15 minutes.

Formulations F1, F2 and F3 were selected as the base formula. They were prepared with three different Babassu oily extracts in the concentration of $10 \mathrm{wt} \%$, extracted from three different regions of Maranhão state (Brazil): forest (BBF, F1), coast (BBC, F2) and lowlands (BBL, F3). The three base formulations were submitted to stability assays.

Formulations F3, F4, F5 and F6 were prepared for evaluation of in vivo efficacy, where skin $\mathrm{pH}$ and hydration were assessed. According to previous studies, Babassu oil extracted from lowlands (BBL) contains the highest quantities of lauric, myristic and oleic acids (7), which are very emollient ingredients that are very well-known in the scientific literature for increasing skin hydration $(21,22)$, thus only the BBL extract was utilised in these analyses. F4 was prepared with BBL oily extract at $10 \%$ and Hidraskin ${ }^{\circledR}$, a standard moisturising ingredient, at $7.5 \mathrm{wt} \%$. F5 was prepared only with Hidraskin ${ }^{\circledR}$ at $7.5 \mathrm{wt} \%$, and F6 was prepared without BBL oily extract or Hidraskin ${ }^{\circledR}($ Table 1). The in vivo efficacy of F3, containing only BBL, was also included for comparison purposes. Hidraskin ${ }^{\circledR}$ is a mixture of glycols, glycerin and sodium lactate and the group decided to use it with the aim to compare this component with the BBL, which has been shown to have a hydration potential.

\section{Stability assays}

The F1, F2 and F3 formulations containing three different Babassu oily extracts (BBF, BBC and BBL) were submitted to stability assays after preparation at the initial time $\left(\mathrm{t}_{0}\right)$ and after $7\left(\mathrm{t}_{7}\right), 14\left(\mathrm{t}_{14}\right), 21\left(\mathrm{t}_{21}\right)$ and 30 $\left(t_{30}\right)$ days. These same formulations were stored under different conditions, refrigerator $\left(2.0 \pm 0.2^{\circ} \mathrm{C}\right)$, room temperature $\left(25 \pm 2^{\circ} \mathrm{C}\right)$ and incubator $\left(40 \pm 2^{\circ} \mathrm{C}\right)$. The following parameters were evaluated: phase separation after centrifugation, $\mathrm{pH}$, density, viscosity and droplets size distribution.

\section{Centrifugation test}

$10.0 \mathrm{~g}$ of each formulation (F1, F2 and F3) were transferred to plastic centrifuge tubes and submitted to $1,000,2,500$ and 3,500 rpm cycles $(121,756$, and 1,485 $g$, respectively) (Avanti J-25 model, Beckman Coulter, USA) for 15 minutes at $25^{\circ} \mathrm{C}$.

\section{pH assessment}

The $\mathrm{pH}$ was assessed by inserting the electrode (Model 922, Bante Instruments, USA) into the F1, F2 and F3 formulations. The $\mathrm{pHmeter}$ was previously calibrated mulações foram agitados mecanicamente até completa homogeneização a 1200 rpm durante 15 minutos.

As formulações F1, F2 e F3 foram selecionadas como formulação base. Foram preparadas com três extratos oleosos de Babaçu, na concentração de 10\% em peso, extraídas de três regiões do Estado do Maranhão: Mata dos Cocais (BBF), Litoral (BBC) e Baixada Maranhense (BBL). As três formulações base foram submetidas a ensaios de estabilidade.

As formulações F3, F4, F5 e F6 foram preparadas para avaliação da eficácia in vivo, onde o $\mathrm{pH}$ e a hidratação da pele foram avaliados. De acordo com estudos anteriores, o óleo de Babaçu extraído da Baixada Maranhense (BBL) contém as maiores quantidades de ácidos láurico, mirístico e oleico (7), que são ingredientes muito emolientes que são bem conhecidos na literatura científica para aumentar a hidratação da pele $(21,22)$, portanto, apenas o extrato BBL foi utilizado nessas análises. F4 foi preparado com extrato oleoso BBL a $10 \% \mathrm{e}$ Hidraskin ${ }^{\circledR}$, um ingrediente hidratante padrão, a 7,5\% em peso. F5 foi preparado apenas com Hidraskin ${ }^{\circledR}$ a 7,5\% em peso, e F6 foi preparado sem extrato oleoso BBL ou Hidraskin ${ }^{\circledR}$ (Tabela 1). A eficácia in vivo de F3, contendo apenas BBL, também foi incluída para fins comparativos. Hidraskin ${ }^{\circledR}$ é uma mistura de glicóis, glicerina e lactato de sódio, e o grupo decidiu usá-lo com o objetivo de comparar este componente com o BBL, o que mostrou ter um potencial de hidratação.

\section{Ensaios de estabilidade}

As formulações F1, F2 e F3 contendo três extratos oleosos de Babaçu (BBF, BBC e BBL) foram submetidas a ensaios de estabilidade após a preparação no tempo inicial $\left(\mathrm{t}_{0}\right)$ e após $7\left(\mathrm{t}_{7}\right), 14\left(\mathrm{t}_{14}\right), 21\left(\mathrm{t}_{21}\right)$ e $30\left(\mathrm{t}_{30}\right)$ dias. Estas mesmas formulações foram armazenadas sob diferentes condições, refrigerador $\left(2,0 \pm 0,2^{\circ} \mathrm{C}\right)$, temperatura ambiente $\left(25 \pm 2^{\circ} \mathrm{C}\right)$ e estufa $\left(40 \pm 2^{\circ} \mathrm{C}\right)$. Os seguintes parâmetros foram avaliados: separação de fases após centrifugação, $\mathrm{pH}$, densidade, viscosidade e distribuição de tamanho de gotículas.

\section{Teste de centrifugação}

10,0 g de cada formulação (F1, F2 e F3) foram transferidos para tubos de plástico de centrífuga e submetidos a ciclos de 1.000, 2.500 e $3.500 \mathrm{rpm}$ (121, 756 e 1.485 g, respectivamente) (modelo Avanti J-25, Beckman Coulter, EUA) durante 15 minutos a $25^{\circ} \mathrm{C}$.

Avaliação do $\mathrm{pH}$

$\mathrm{O}$ pH foi avaliado por inserção do eletrodo (modelo 922, Bante Instruments, EUA) nas formulações F1, F2 e F3. O pHmetro foi previamente calibrado com solu- 
with standard solutions, pHs 4.0 and 10.0 (Hanna Instruments, USA). Measurements were performed in triplicate at $25^{\circ} \mathrm{C}$. The mean \pm standard deviation (SD) was calculated.

\section{Density}

The densities of F1, F2 and F3 formulations were obtained using a glass pycnometer (Pyrex ${ }^{\circledR}$ 1620-25, Corning Life Sciences, EUA). Density for each sample was assessed according to Equation 1. Prior to initiation of measurements, the weight of the empty pycnometer in its dry state was noted.

$$
\left.\rho=\left(m_{2}-m_{0}\right)\right) /\left(m 1-m_{0}\right)
$$

Where $m_{2}$ is the weight of the pycnometer with the sample, $\mathrm{m}_{1}$ is weight of the pycnometer with distilled water at $25^{\circ} \mathrm{C}$ and $\mathrm{m}_{0}$ is the weight of the empty pycnometer (23). Measurements were performed in triplicate.

\section{Viscosity}

Viscosity was measured using a rotary digital viscometer (DV-II model, Brookfield $\AA$, USA) with spindle number 94 and rotation speeds of $0.3,0.6,1.5,3,6,12$, 30 and $60 \mathrm{rpm}$. The spindle was vertically immersed into $42 \mathrm{~g}$ of each F1, F2 and F3 formulation at $25^{\circ} \mathrm{C}$. Measurements were performed in triplicate.

\section{Analysis of droplets size distribution}

Droplets size distributions of the F1, F2 and F3 formulations were determined by laser diffraction technique (Malvern Scirocco® 2000 Mastersizer, UK). The equipment measures the intensity of light scattered as a laser beam passes through a dispersed particulate/emulsifiedsample. This data is then analyzed to calculate the size of the droplets that created the scattering pattern. Samples were diluted in distilled water at the ratio of $1: 1000$. Measurements were performed in triplicate at $25^{\circ} \mathrm{C}(24)$.

\section{Assessment of globule homogeneity by microscopy}

Using a photonic binocular microscope (Leica DMLS ${ }^{\circledR}$ Ltda, USA) coupled to a digital camera (Moticam ${ }^{\circledR}$ 1000, USA) and software (Motic Image Plus 2.0), the globules were observed in photomicrographs with $40 \mathrm{x}$ increase. Approximately $0.1 \mathrm{~g}$ of each formulation was used, diluted with 1 drop of distilled water and placed on a microscopic slide (Perfecta ${ }^{\circledR}$ AG -1.0 to $1.2 \mathrm{~mm}$ thickness) under a pressure cover slip. ções padrão, pH 4,0 e 10,0 (Hanna Instruments, EUA). As medições foram realizadas em triplicata a $25^{\circ} \mathrm{C}$. Foi calculada a média \pm desviopadrão (DP).

\section{Densidade}

As densidades das formulações F1, F2 e F3 foram obtidas utilizando um picnômetro de vidro (Pyrex ${ }^{\circledR} 1620$ 25, Corning Life Sciences, EUA). A densidade para cada amostra foi avaliada de acordo com a Equação 1. Antes do início das medições, observou-se o peso do picnômetro vazio em seu estado seco.

$$
\left.\rho=\left(m_{2}-m_{0}\right)\right) /\left(m 1-m_{0}\right)
$$

Onde $\mathrm{m}_{2}$ é o peso do picnômetro com a amostra, $\mathrm{m}_{1}$ é o peso do picnômetro com água destilada a $25^{\circ} \mathrm{C}$ e $\mathrm{m}_{0}$ é o peso do picnômetro vazio (23). As medições foram realizadas em triplicata.

\section{Viscosidade}

A viscosidade foi medida usando um viscosímetro digital rotativo (modelo DV-II, Brookfield ${ }^{\circledR}$, USA) com spindle de número 94 e velocidades de rotação de 0,3 , $0,6,1,5,3,6,12,30$ e $60 \mathrm{rpm}$. O spindle foi imerso verticalmente em $42 \mathrm{~g}$ de cada formulação F1, F2 e F3 a $25^{\circ} \mathrm{C}$. As medições foram realizadas em triplicata.

\section{Análise da distribuição de tamanho de gotículas}

As distribuições de tamanho das gotículas das formulações F1, F2 e F3 foram determinadas por técnica de difração de laser (Malvern Scirocco ${ }^{\circledR} 2000$ Mastersizer, Reino Unido). O equipamento mede a intensidade da luz dispersa quando um feixe de laser passa através das partículas dispersas/ amostra emulsionada. Estes dados são então analisados para calcular o tamanho das gotículas que criaram o padrão de dispersão. As amostras foram diluídas em água destilada na proporção de 1:1000. As medições foram realizadas em triplicata a $25^{\circ} \mathrm{C}(24)$.

Avaliação da homogeneidade dos glóbulos por microscopia

Usando um microscópio binocular fotônico (Leica DMLS® Ltda, EUA) acoplado a uma câmera digital (Moticam ${ }^{\circledR} 1000$, EUA) e software (MoticImage Plus 2.0), os glóbulos foram observados em fotomicrografias com aumento de 40x. Aproximadamente $0,1 \mathrm{~g}$ de cada formulação foi utilizada, diluída com 1 gota de água destilada e colocada sobre uma lâmina microscópica (Perfecta ${ }^{\circledR} A G-1,0$ a $1,2 \mathrm{~mm}$ de espessura) sob pressa de lamínula. 
In vivo efficacy assays by cutaneous biometry: $p H$ and moisture evaluation of the skin

The in vivo study protocol was approved by the Scientific Ethical Committee of Federal University of Rio de Janeiro, Brazil (number 42610115.0.0000.5257). The study was conducted in a room under controlled conditions (temperature of $24 \pm 2{ }^{\circ} \mathrm{C}$ and relative humidity of $45 \pm 5 \%$ ). The test was performed on 16 volunteers (3 men and 13 women with ages $31 \pm 9$ years), who indicated that they had understood the purpose of the trial and signed the consent form. The skin phototype of the volunteers ranged from white to light brown skin. No volunteer presented any type of dermatological disease before and after the tests.

Before the application ( $1^{\text {st }}$ to $4^{\text {th }}$ days) and after the measurements $\left(5^{\text {th }}\right.$ day), the volunteers waited for 7 minutes to acclimate without covering the skin sites. After the application, volunteers waited for the formulations to dry (15 minutes). According to the study participation protocol (which included specific inclusion and non-inclusion/ exclusion criteria), volunteers were instructed not to expose to sunlight or to use any cosmetic products (only water during the shower) on the forearm sites where the formulations were applied.

A fixed amount of $32 \mathrm{mg}$ of F3 (BBL), F4, F5 and F6 was applied randomly once a day for four consecutively days on the volunteers' forearms, and skin measurements were performed only on the 5th day (22). Four sites were marked on the skin forearms $\left(16 \mathrm{~cm}^{2}\right.$ each) where the formulations were applied. Each formulation presented its control site (next to the product site) where no formulation was applied (Figure 1).
Ensaios de eficácia in vivo por biometria cutânea: avaliação do $\mathrm{pH}$ e da humidade da pele

O protocolo de estudo in vivo foi aprovado pelo Comitê Científico de Ética da Universidade Federal do Rio de Janeiro, Brasil (número 42610115.0.0000.5257). O estudo foi realizado em uma sala sob condições controladas (temperatura de $24 \pm 2{ }^{\circ} \mathrm{C}$ e humidade relativa de $45 \pm 5 \%$ ). O teste foi realizado em 16 voluntários (3 homens e 13 mulheres com idades de $31 \pm 9$ anos), que indicaram que entenderam o propósito do teste e assinaram o termo de consentimento antes da participação no estudo. O fototipo de pele dos voluntários variou de pele branca a morena clara. Nenhum voluntário apresentou algum tipo de doença dermatológica antes e após os testes.

Antes da aplicação ( $1^{\circ}$ a $4^{\circ}$ dias $)$ e após as medições $\left(5^{\circ}\right.$ dia), os voluntários aguardaram por 7 minutos para aclimatar sem cobrir os locais da pele. Após a aplicação, os voluntários aguardaram a secagem das formulações (15 minutos). De acordo com o protocolo de participação no estudo (que previa critérios específicos de inclusão e não-inclusão/ exclusão), os voluntários foram instruídos a não expor à luz solar ou utilizar qualquer produto cosmético (apenas água durante o banho) nos locais do antebraço onde as formulações foram aplicadas.

Uma quantidade fixa de $32 \mathrm{mg}$ de F3 (BBL), F4, F5 e F6 foi aplicada aleatoriamente uma vez por dia durante quatro dias consecutivos nos antebraços dos voluntários e as medidas da pele foram realizadas apenas no $5^{\circ}$ dia (22). Quatro locais foram marcados na pele dos antebraços $\left(16 \mathrm{~cm}^{2}\right.$ cada) onde as formulações foram aplicadas. Cada formulação apresentou seu local de controle (próximo ao local do produto) onde nenhuma formulação foi aplicada (Figura 1).

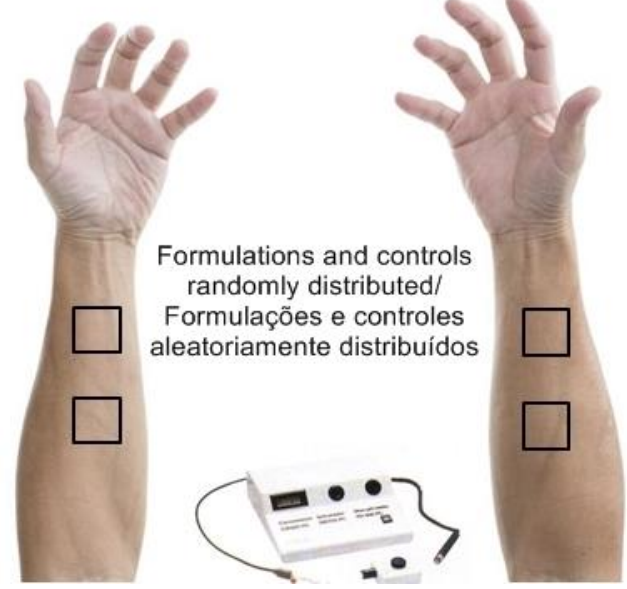

Figure 1/ Figura 1 - Four sites marked on the skin forearms, each one with $16 \mathrm{~cm} 2$ Quatro locais marcados na pele do antebraço, cada um com $16 \mathrm{~cm} 2$ 
Measurements of hydration levels and $\mathrm{pH}$ of the forearm skin (anterior surface) were performed using a Corneometer and pHmeter, respectively, combined in one device (Corneometer CM 825/skin-pH-meter PH 900, Courage and Khazaka GmbH, Cologne, Germany). This equipment allows noninvasive measurements. The skin surface $\mathrm{pH}$ of the forearms was measured with a flat glass electrode with a precision of $0.1 \mathrm{pH}$-unit. The resulting $\mathrm{pH}$ value was displayed after 3 seconds. The measuring principle of the Corneometer is based on the capacitance measurement of a dielectric medium. Any change in the dielectric constant due to skin surface hydration variation changes the capacitance. The capacitance was expressed digitally in arbitrary units (a.u.).

\section{Statistical analysis}

All data were analyzed using Origin Pro 8 software (OriginLab, USA). Experimental data were presented as mean \pm SD (standard error) and $p<0.05$ was considered to be statistically significant.

\section{Results}

\section{Stability assays}

$\mathrm{F} 1, \mathrm{~F} 2$ and $\mathrm{F} 3$ formulations (containing $\mathrm{BBF}, \mathrm{BBC}$ and $\mathrm{BBL}$ ) were stable during the period of study (30 days). They presented a creamy and bright appearance and a characteristic odor of Babassu oil.

The centrifugation test was used as part of a process of elimination: centrifugal force accelerates sedimentation, creaming or coalescence of the systems, which could reveal any preliminary instability $(25,26)$. F1, F2 and $\mathrm{F} 3$ formulations did not present creaming or phase separation.

All F1 (BBF), F2 (BBC) and F3 (BBL) formulations (stored at 2, 25 and $40^{\circ} \mathrm{C}$ ) presented $\mathrm{pH}$ values around 6.0 to 7.0 , during the entire evaluation period. Concerning the density results, F1 (BBF), F2 (BBC) and F3 (BBL) formulations presented density values ranging from: $0.95 \pm 0.02 \mathrm{~g} / \mathrm{mL}$ at room temperature $\left(25^{\circ} \mathrm{C}\right)$, $0.96 \pm 0.02 \mathrm{~g} / \mathrm{mL}$ in the incubator $\left(40^{\circ} \mathrm{C}\right)$ and $0.93 \pm$ $0.01 \mathrm{~g} / \mathrm{mL}$ in the refrigerator $\left(2^{\circ} \mathrm{C}\right)$ over the 30 day period, without intra-group differences $(\mathrm{p}>0.05)$.

Figure 2 shows the viscosity results. Flow curves of $\mathrm{F} 1, \mathrm{~F} 2$ and $\mathrm{F} 3$ formulations (with BBF, BBC and BBL) demonstrate that there is no linear relationship between the values of viscosity (cP.s) and the rotational speed gradient applied to the samples.
As medições dos níveis de hidratação e do $\mathrm{pH}$ da pele do antebraço (superfície anterior) foram realizadas utilizando um Corneometer e pHmetro, respectivamente, combinados em um dispositivo (Corneometer CM 825/ skin-pH-meter PH 900, Courage and Khazaka GmbH, Colônia, Alemanha). Este equipamento permite medições não invasivas. $\mathrm{O} \mathrm{pH}$ da superfície da pele dos antebraços foi medido com um eletrodo de vidro plano com uma precisão de 0,1 unidades de $\mathrm{pH}$. $\mathrm{O}$ valor de $\mathrm{pH}$ resultante foi exibido após 3 segundos. O princípio de medição do Corneometer baseia-se na medição de capacitância de um meio dielétrico. Qualquer alteração na constante dielétrica devido à variação da hidratação da superfície da pele altera a capacitância. A capacitância foi expressa digitalmente em unidades arbitrárias (a.u.).

\section{Análise estatística}

Todos os dados foram analisados utilizando o software Origin Pro 8 (OriginLab, EUA). Os dados experimentais foram apresentados como média $\pm \mathrm{DP}$ (erro padrão) e $p<0,05$ foi considerado como estatisticamente significativo.

\section{Resultados}

\section{Ensaios de estabilidade}

As formulações F1, F2 e F3 (contendo BBF, BBC e $\mathrm{BBL}$ ) foram estáveis durante o período de estudo (30 dias). Apresentaram uma aparência cremosa e brilhante e um odor característico de óleo de Babaçu.

O teste de centrifugação foi utilizado como parte de um processo de eliminação: a força centrífuga acelera a sedimentação, cremeação ou coalescência dos sistemas, o que pode revelar qualquer instabilidade preliminar $(25,26)$. As formulações F1, F2 e F3 não apresentaram cremeação ou separação de fases.

Todas as formulações F1 (BBF), F2 (BBC) e F3 (BBL) (armazenadas a 2,25 e $40^{\circ} \mathrm{C}$ ) apresentaram valores de $\mathrm{pH}$ em torno de 6,0 a 7,0 durante todo o período de avaliação.Com relação aos resultados de densidade, as formulações F1 (BBF), F2 (BBC) e F3 (BBL) apresentaram valores de densidade de: $0,95 \pm 0,02 \mathrm{~g} / \mathrm{mL}$ à temperatura ambiente $\left(25^{\circ} \mathrm{C}\right), 0,96 \pm 0,02 \mathrm{~g} / \mathrm{mL}$ na estufa $\left(40^{\circ} \mathrm{C}\right)$ e $0,93 \pm 0,01 \mathrm{~g} / \mathrm{mL}$ na geladeira $\left(2^{\circ} \mathrm{C}\right)$ ao longo do período de 30 dias, sem diferenças entre grupos $(\mathrm{p}>$ $0,05)$.

A Figura 2 mostra os resultados de viscosidade. As curvas de fluxo das formulações F1, F2 e F3 (com BBF, $\mathrm{BBC}$ e $\mathrm{BBL}$ ) demostram que não há relação linear entre os valores de viscosidade (cP.s) e o gradiente de velocidade de rotação aplicado às amostras. 

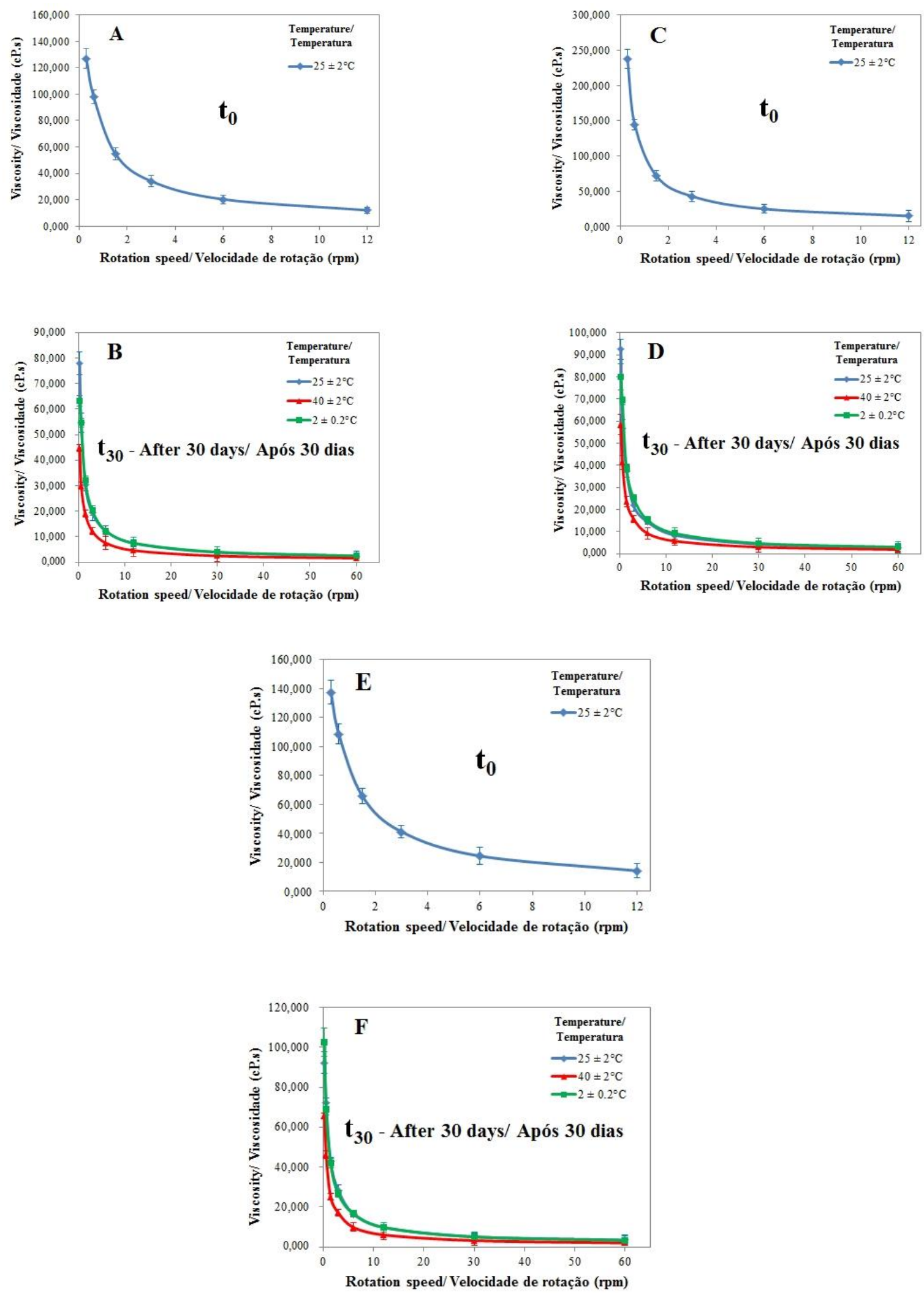

Figure 2/ Figura 2 - Rheograms of formulations: A) and B) F1 (containing BBF), t0 $\left(25^{\circ} \mathrm{C}\right)$ and t30 $\left(2,25\right.$ and $\left.40^{\circ} \mathrm{C}\right)$, respectively; C) and D) F2 (containing BBC), t0 $\left(25^{\circ} \mathrm{C}\right)$ and $\mathrm{t} 30\left(2,25\right.$ and $\left.40^{\circ} \mathrm{C}\right)$, respectively; E) and F) F3 (containing $\mathrm{BBL}$, t $0\left(25^{\circ} \mathrm{C}\right)$ and $\mathrm{t} 30\left(2,25\right.$ and $\left.40^{\circ} \mathrm{C}\right)$, respectively. Error bars indicate SD for the triplicates $(\mathrm{n}=3)$

Reogramas das formulaccões: A) e B) F1 (contendo BBF), t0 $\left(25^{\circ} \mathrm{C}\right)$ e $\mathrm{t30}\left(2,25\right.$ e $\left.40^{\circ} \mathrm{C}\right)$, respectivamente; C) e D) F2 (contendo $\mathrm{BBC})$, t0 $\left(25^{\circ} \mathrm{C}\right)$ e t30 $\left(2,25\right.$ e $\left.40^{\circ} \mathrm{C}\right)$, respectivamente; E) e F) F3 (contendo BBL), t0 $\left(25^{\circ} \mathrm{C}\right)$ e t30' $\left(2,25\right.$ e $\left.40^{\circ} \mathrm{C}\right)$, respectivamente. As barras de erro indicam DP para as triplicatas $(n=3)$ 
Although Babassu oily extracts were collected from different regions and the number of rotations applied and storage temperatures were also distinct, no statistically significant differences in mean viscosity were observed among F1, F2 and F3 formulations ( $\mathrm{p}>0.05$ ).

Regarding the droplets mean size and size distribution, all formulations (F1, F2 and F3) presented the same pattern of droplets size distribution and mean size for over 30 days (Figure 3). Mean droplets size values did not present statistical differences $(\mathrm{p}>0.05)$ among the formulations in different times and storage temperatures. Emulsion photomicrographs (40x amplification) showed that the formulations have small oil globules dispersed in the external phase (water).
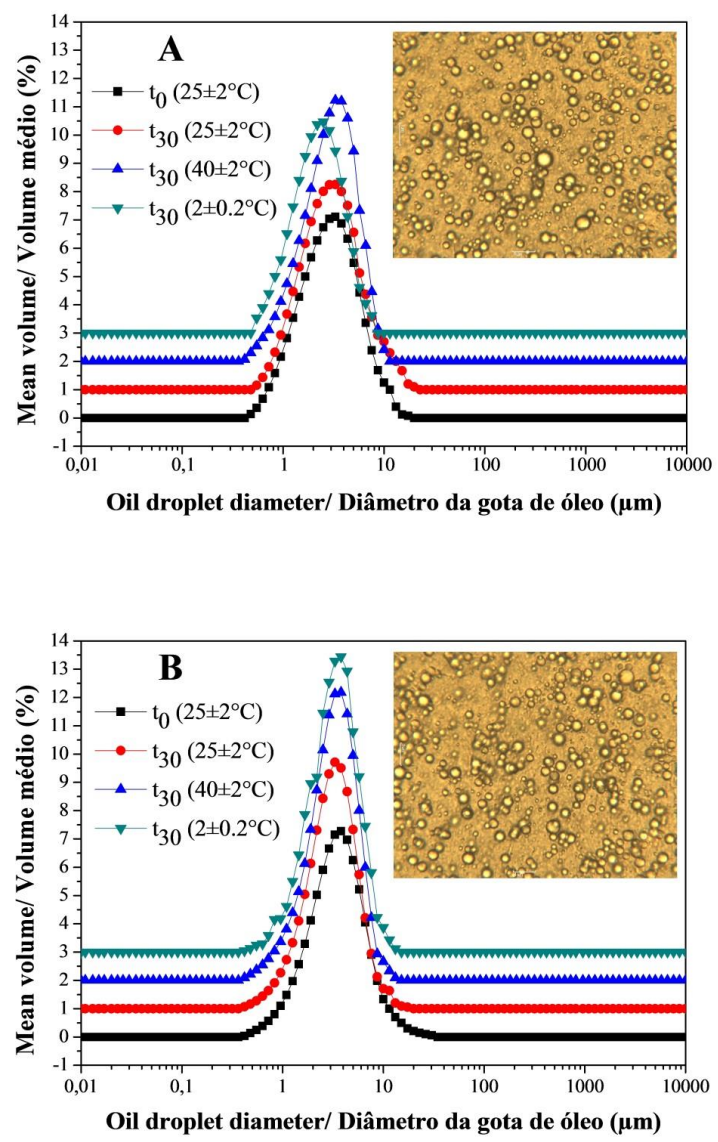

Embora os extratos oleosos de Babaçu tenham sido coletados de diferentes regiões, o número de rotações aplicadas e as temperaturas de armazenamento também foram distintas, não foram observadas diferenças estatisticamente significativas na viscosidade média entre formulações F1, F2 e F3 (p> 0,05).

Em relação ao tamanho médio e distribuição de tamanho das gotas, todas as formulações (F1, F2 e F3) apresentaram o mesmo padrão de distribuição de tamanho de gotículas e o tamanho médio por mais de 30 dias (Figura 3). Os valores médios de tamanho de gotículas não apresentaram diferenças estatísticas $(p>0,05)$ entre as formulações em diferentes tempos e temperaturas de armazenamento. As fotomicrografias das emulsões (aumento 40x) mostraram que as formulações contêm pequenos glóbulos de óleo dispersos na fase externa (água).

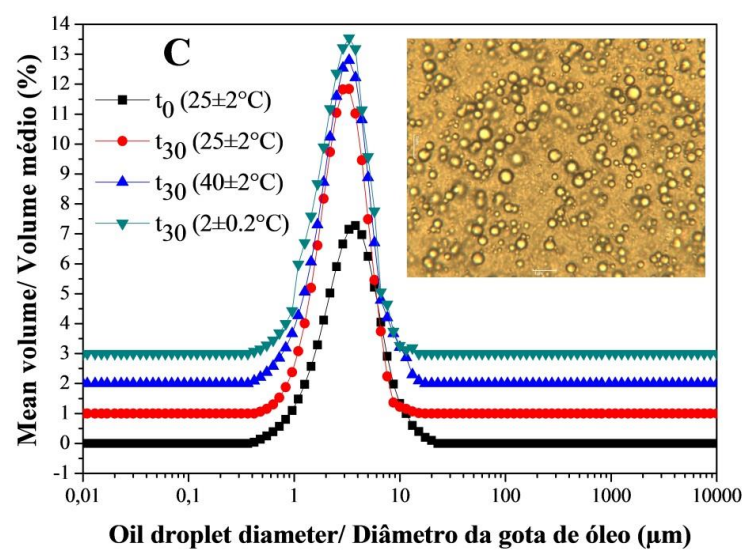

Figure 3/ Figura 3 - Droplets mean size and size distribution for formulations: A) F1 containing $\mathrm{BBF}$, t0 $\left(25^{\circ} \mathrm{C}\right)$ and $\mathrm{t} 30\left(2,25\right.$ and $\left.40^{\circ} \mathrm{C}\right)$; B $) \mathrm{F} 2$ containing $\mathrm{BBC}$, t0 $\left(25^{\circ} \mathrm{C}\right)$ and $\mathrm{t} 30\left(2,25\right.$ and $\left.40^{\circ} \mathrm{C}\right)$; C $) \mathrm{F} 3$ containing $\mathrm{BBL}, \mathrm{t} 0\left(25^{\circ} \mathrm{C}\right)$ and $\mathrm{t} 30\left(2,25\right.$ and $\left.40^{\circ} \mathrm{C}\right)$

Tamanho médio das gotas e distribuição de tamanho para as formulações: A) F1 contendo BBF, t0 $\left(25^{\circ} \mathrm{C}\right)$ e t $30\left(2,25^{\circ}\right.$ e $\left.40^{\circ} \mathrm{C}\right)$; B $) \mathrm{F} 2$ contendo $\mathrm{BBC}$, t0 $\left(25^{\circ} \mathrm{C}\right) \mathrm{e}$ t30 $\left(2,25\right.$ e $\left.40^{\circ} \mathrm{C}\right)$; C) $\mathrm{F} 3$ contendo BBL, t0 $\left(25^{\circ} \mathrm{C}\right)$ e t30 $\left(2,25\right.$ e $\left.40^{\circ} \mathrm{C}\right)$ 
In vivo efficacy assays by cutaneous biometry: $p H$ and moisture evaluation of the skin

Skin hydration enhancement (\%) and skin $\mathrm{pH}$ were assessed for each formulation (F3 BBL, F4, F5 and F6) based the on comparison between control site and product site in both volunteer forearms. Then, mean \pm SD was assessed for each formulation (Figure 4).

F3 (BBL) did not present any statistical difference concerning the skin hydration enhancement (20.12 $\pm 3.34 \%)$ when compared to F4 (19.49 $\pm 1.75 \%)(\mathrm{p}>$ $0.05)$. However it presented statistical difference when compared to F5 $(13.13 \pm 2.81 \%)$ and F6 $(10.58 \pm$ $4.73 \%)(p<0.05)$. The same result was observed to F4, presenting a skin hydration enhancement value statistically highercompared to F5 and F6 values $(\mathrm{p}<0.05)$. When comparing F5 and F6, the skin hydration enhancement values obtained were not statically different $(p>0.05)$; however these values were statistically lower when compared to the values obtained for F3 and F4 $(\mathrm{p}<0.05)$.

No changes occurred in skin $\mathrm{pH}$ values $(\mathrm{p}>0.05)$ after the product application, which can be viewed as a positive result, sincea cosmetic formulation should not interfere in the physiological skin surface $\mathrm{pH}$.
Ensaios de eficácia in vivo por biometria cutânea: avaliação do $\mathrm{pH}$ e da humidade da pele

$\mathrm{O}$ aumento da hidratação da pele (\%) e o pH da pele foram avaliados para cada formulação (F3 BBL, F4, F5 e F6) com base na comparação entre o local de controle e o local do produto em ambos os antebraços dos voluntários. Em seguida, a média \pm DP foi avaliada para cada formulação (Figura 4).

F3 (BBL) não apresentou diferença estatística no aumento da hidratação da pele $(20,12 \pm 3,34 \%)$ quando comparado ao F4 $(19,49 \pm 1,75 \%)(p>0,05)$. No entanto, apresentou diferença estatística quando comparado com F5 $(13,13 \pm 2,81 \%)$ e F6 $(10,58 \pm 4,73 \%)$ (p $<0,05)$. O mesmo resultado foi observado para F4, que apresenta um valor de aumento da hidratação da pele estatisticamente maior quando comparado aos valores de F5 e F6 ( $<$ <,05). Ao comparar F5 e F6, os valores de aumento da hidratação da pele obtidos não foram estaticamente diferentes $(\mathrm{p}>0,05)$. Porém estes valores foram estatisticamente menores quando comparados aos valores obtidos para F3 e F4 ( $\mathrm{p}<0,05)$.

Não houve alterações nos valores de $\mathrm{pH}$ da pele $(\mathrm{p}>$ $0,05)$ após a aplicação do produto, o que pode ser visto como um resultado positivo, uma vez que uma formulação cosmética não deve interferir no pH fisiológico da superfície cutânea.

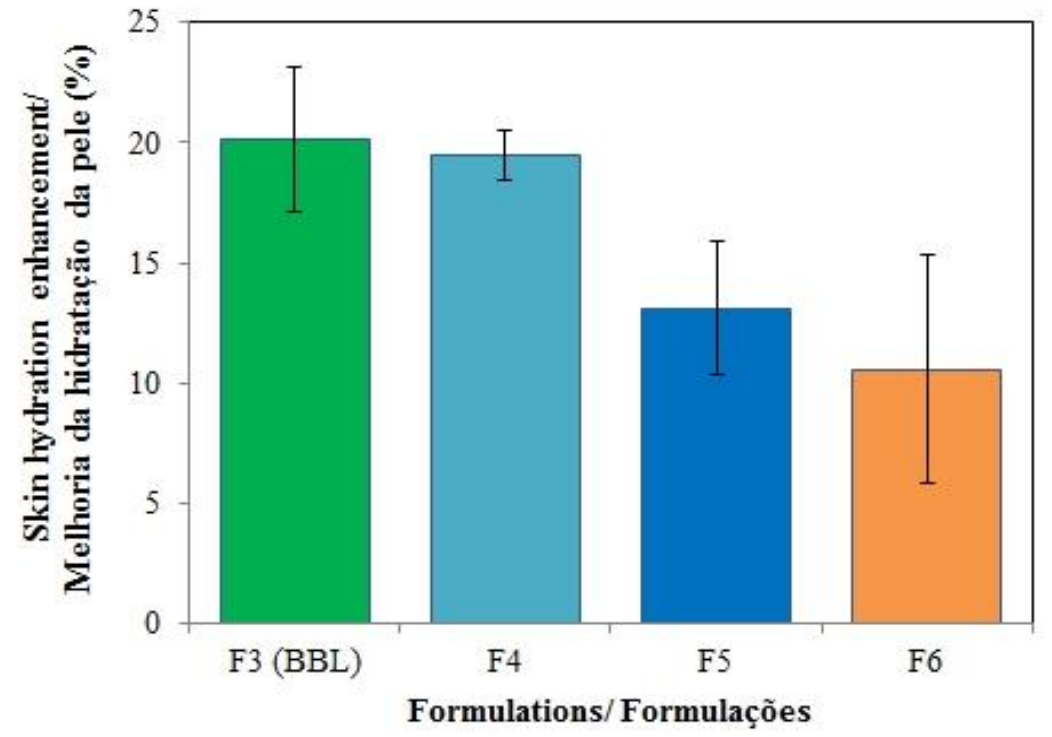

Figure 4/ Figura 4 - Results of skin hydration enhancement (\%) for F3 (BBL), F4, F5 and F6

Resultados do aumento da hidratação da pele (\%) para F3 (BBL), F4, F5 e F6 


\section{Discussion}

\section{Stability assays}

A decrease in $\mathrm{pH}$ was observed for the $\mathrm{F} 1$ (BBF), F2 (BBC) and $\mathrm{F} 3(\mathrm{BBL})$ formulations stored in the incubator at $40^{\circ} \mathrm{C}(6.0 \pm 0.2)$ when compared to the other temperatures, refrigerator at $2^{\circ} \mathrm{C}(6.5 \pm 0.3)$ and at room temperature at $25^{\circ} \mathrm{C}(6.1 \pm 0.4)$ after 30 days.According to Martins and coworkers (9), elevated temperatures in emulsified systems containing lipids may cause a slight oxidation of the oily phase, with the formation of hydroperoxides or even the hydrolysis of triglycerides, leading to the formation of fatty acids and for this reason to a reduction in $\mathrm{pH}$ values.Skin presents a $\mathrm{pH}$ around 6, mainly in arms, legs and trunk. Therefore, the $\mathrm{pH}$ values obtained in this study were compatible to the skin, thus preventing skin allergies and making the formulations promising candidates for topical application (27-29).

Concerning the viscosity results, the same study demonstrated that all $\mathrm{F} 1, \mathrm{~F} 2$ and $\mathrm{F} 3$ formulations $\mathrm{t}_{0}$ and after 30 days $\left(\mathrm{t}_{30}\right)$ presented non-Newtonian fluid characteristics with pseudoplastic behavior $(13,26,30,31)$. Pseudoplastic behavior is ideal for products to be applied topically, since after overcoming the initial resistance to flow, viscosity decreases enabling easy application of the product on the skin (32). The flow curves obtained show similar decreasing viscosity when the rotational speed (shear rate) is increased $(33,34)$.

For all formulations, viscosity decreasing when rotational speed increases could be associated to thixotropy, a time-dependent shear thinning property. Thixotropic products become more fluid when subjected to an external pressure, spreading easily and recovering the initial viscosity after application, which prevents the product from dripping (32).

Analyzing Figure 2, it was possible to observe that in $\mathrm{t}_{0}\left(25^{\circ} \mathrm{C}\right), \mathrm{F} 2 \mathrm{BBC}$ presented the highest viscosity, initially at the rotation speed of $0.3 \mathrm{rpm}$. However, in $\mathrm{t}_{30}$, F3 BBL presented the highest apparent viscosity at the same temperature $\left(25^{\circ} \mathrm{C}\right)$. Viscosity changed with time and storage conditions: at $2^{\circ} \mathrm{C}$ emulsions $\mathrm{BBC}$ and $\mathrm{BBL}$ presented the lowest viscosity values, while at $40^{\circ} \mathrm{C}$ it was obtained the highest viscosity values (Figure 2). F1 BBF presented the lowest viscosity at all temperatures. An emulsion's viscosity can be altered by lipid composition, by aqueous and oil phases ratio, by the concentration of the emulsifiers and by the addition of polymers. Consumer acceptance depends on the sensorial, spreadability and residual oiliness of the product after application. A cosmetic emulsion should present

\section{Discussão}

\section{Ensaios de estabilidade}

Foi observada uma diminuição no $\mathrm{pH}$ das formulações F1 (BBF), F2 (BBC) e F3 (BBL) armazenadas na estufa a $40^{\circ} \mathrm{C}(6,0 \pm 0,2)$ quando comparadas com as demais temperaturas, geladeira a $2^{\circ} \mathrm{C}(6,5 \pm 0,3)$ e à temperatura ambiente a $25^{\circ} \mathrm{C}(6,1 \pm 0,4)$ após 30 dias. De acordo com Martins e colaboradores (9), temperaturas elevadas em sistemas emulsionados contendo lipídeos podem causar uma ligeira oxidação da fase oleosa, com a formação de hidroperóxidos ou mesmo a hidrólise de triglicerídeos, levando à formação de ácidos graxos e, redução nos valores de $\mathrm{pH}$. A pele apresenta um $\mathrm{pH}$ em torno de 6, principalmente nos braços, pernas e tronco. Por isso, os valores de $\mathrm{pH}$ obtidos neste estudo foram compatíveis com a pele, prevenindo assim alergias cutâneas e tornando as formulações promissoras candidatas para aplicação tópica (27-29).

Quanto aos resultados de viscosidade, o mesmo estudo demonstrou que todas as formulações F1, F2 e F3 em $\mathrm{t}_{0}$ e após 30 dias $\left(\mathrm{t}_{30}\right)$ apresentaram características de fluidos não-newtonianos com comportamento pseudoplástico $(13,26,30,31)$. O comportamento pseudoplástico é ideal para que os produtos sejam aplicados topicamente, uma vez que após a superação da resistência inicial ao fluxo, a viscosidade diminui permitindo a fácil aplicação do produto sobre a pele (32). As curvas de fluxo obtidas mostraram uma viscosidade decrescente semelhante quando a velocidade de rotação (taxa de cisalhamento) é aumentada $(33,34)$.

Para todas as formulações, a diminuição da viscosidade com o aumentoda velocidade de rotação, pode estar associada à tixotropia, uma propriedade de afinamento de cisalhamento dependente do tempo. Os produtos tixotrópicos tornam-se mais fluidos quando submetidos a uma pressão externa, se espalhando facilmente e recuperando a viscosidade inicial após a aplicação, o que evita que o produto goteje (32).

Analisando a Figura 2, foi possível observar que em $\mathrm{t}_{0}\left(25^{\circ} \mathrm{C}\right), \mathrm{F} 2 \mathrm{BBC}$ apresentou a viscosidade mais alta, inicialmente à velocidade de rotação de $0,3 \mathrm{rpm}$. No entanto, em $\mathrm{t}_{30}, \mathrm{~F} 3 \mathrm{BBL}$ apresentou a maior viscosidade aparente à mesma temperatura $\left(25^{\circ} \mathrm{C}\right)$. A viscosidade mudou com o tempo e as condições de armazenamento: as emulsões a $2^{\circ} \mathrm{C} \mathrm{BBC}$ e BBL apresentaram os menores valores de viscosidade, enquanto a $40^{\circ} \mathrm{C}$ obtiveram-se os valores de viscosidade mais elevados (Figura 2). F1 BBF apresentou a menor viscosidade a todas as temperaturas. A viscosidade de uma emulsão pode ser alterada pela composição lipídica, por proporção de fases 
viscosity enabling its long-lasting contact with the skin, however its spreadability should not be affected by high viscosity values $(32,35)$.

Regarding the droplet size, according to Robins and coworkers (30) and Merryweather (31), an O/W emulsion should present a dispersed phase of small oil droplets with diameters ranging from 1 to $10 \mu \mathrm{m}$. F1, F2 and F3 formulations presented droplets mean size between 7 and $10 \mu \mathrm{m}$, which confirms that these formulations containing Babassu oily extracts have a proper size for a cosmetic emulsion $(13,30,31)$. Based on microscopic observation, we verified that the smaller and more homogeneous the globules, the greater a formulation's tendency toward stability. Emulsions with a large number of small cells are highly efficient as pharmaceuticals and/or cosmetics (36).

\section{In vivo efficacy assays by cutaneous biometry: $\mathrm{pH}$ and} moisture evaluation of the skin

Some authors have demonstrated that the essential fatty acids, lauric (C12:0), myristic (C14:0) and oleic (C18:1) from palm oils such as Babassu, promote good skin hydration $(37,38)$. As all of the tested (F1, F2 and F3) formulations containing Babassu oils were shown to be stable, the choice criteria for the oil source to be studied for skin hydration potential and $\mathrm{pH}$ effects was based on the chemical composition and concentrations of essential fatty acids present in the Babassu oils, previously determined (7) to be that of the Babassu oil collected from the Lowlands (BBL).

In previous research group studies, Santos and coworkers (7) performed a chromatographic analysis to quantify the fatty acids present in different samples of oils from Babassu the Maranhão State (Brazil). According to the authors, the Babassu oil collected from Lowlands (BBL) present the highest concentration of lauric acid $(52.15 \%)$, as well relevant concentrations of myristic acid (16.58\%) and oleic acid (15.13\%), when compared to the other oils in this study. For this reason, BBL oily extract was selected to take part of the formulations to be evaluated in this study concerning the skin hydration potential and skin $\mathrm{pH}$.

According to the results shown in Figure 4, all formulations increased the skin moisture when compared to the skin control sites (without product application). The incorporation of emollients from vegetable oils as topi- aquosa e oleosa, pela concentração dos emulsionantes e pela adição de polímeros. A aceitação do consumidor depende da sensibilidade, espessabilidade e oleosidade residual do produto após a aplicação. Uma emulsão cosmética deve apresentar viscosidade que permita o seu contato duradouro com a pele, mas a sua capacidade de espalhar não deve ser afetada por valores de viscosidade elevados $(32,35)$.

Em relação ao tamanho das gotas, segundo Robins e colaboradores (30) e Merryweather (31), uma emulsão $\mathrm{O} / \mathrm{A}$ deve apresentar uma fase dispersa de pequenas gotículas de óleo com diâmetros variando de 1 a $10 \mu \mathrm{m}$. As formulações F1, F2 e F3 apresentaram tamanho médio de gotículas entre 7 e $10 \mu \mathrm{m}$, o que confirma que estas formulações contendo extratos oleosos de Babaçu têm tamanho adequado para uma emulsão cosmética $(13,30,31)$. Com base na observação microscópica, verificamos que quanto menores e homogêneos os glóbulos, maior a tendência de uma formulação para a estabilidade. As emulsões com um grande número de células pequenas são altamente eficientes como produtos farmacêuticos e/ou cosméticos (36).

Ensaios de eficácia in vivo por biometria cutânea: avaliação do $\mathrm{pH}$ e da humidade da pele

Alguns autores demonstraram que os ácidos graxos essenciais, láurico (C12:0), mirístico (C14:0) e oleico (C18:1) de óleos de palma, como o Babaçu, promovem uma boa hidratação da pele $(37,38)$. Como todas as formulações testadas (F1, F2 e F3) contendo óleos de Babaçu mostraram-se estáveis, o critério de escolha da fonte de óleo para os estudos do potencial de hidratação da pele e os efeitos do $\mathrm{pH}$, foram baseados na composição química e nas concentrações de ácidos graxos essenciais presentes nos óleos de Babaçu, previamente determinado (7) como o óleo de Babaçu coletado na Baixada Maranhense (BBL).

Em estudos anteriores do grupo de pesquisa, Santos e colaboradores (7) realizaram uma análise cromatográfica para quantificar os ácidos graxos presentes em diferentes amostras de óleos de Babaçu do Estado do Maranhão (Brasil). De acordo com os autores, o óleo de Babaçu obtido da Baixada Maranhense (BBL) apresenta a maior concentração de ácido láurico (52,15\%), bem como concentrações relevantes de ácido mirístico $(16,58 \%)$ e ácido oleico $(15,13 \%)$ quando comparado com outros óleos deste estudo. Por esta razão, o extrato oleoso BBL foi selecionado para fazer parte das formulações a serem avaliadas neste estudo quanto ao potencial de hidratação da pele e $\mathrm{pH}$ da pele.

De acordo com os resultados mostrados na Figura 4, todas as formulações aumentaram a humidade da pele 
cal components may act by providing lipid content and thus protection to the skin matrix. Also, these lipids are able to help in the treatment of some skin diseases such as psoriasis and atopic dermatitis, caused by abnormal skin barrier function (39).

The addition of Hidraskin ${ }^{\circledR}$ in F4 did not appear to improve skin hydration, as F3 was prepared with only $\mathrm{BBL}$ and presented the same moisturising effect on the skin. It could be suggested that since the formulation base that was chosen to this study presented skin conditioning, emollient and humectant ingredients (e.g. cetostearyl alcohol ethoxylate, glyceryl monostearate and glycerin), F6 presented a hydration potential even without containing Hidraskin ${ }^{\circledR}$ or BBL.

Regarding the skin $\mathrm{pH}$, the results obtained (Figure 5) are in agreement with the findings of Wagner and coworkers (27), in which the researchers verified that formulations with $\mathrm{pH}$ from 5.0 to 7.0 are compatible with skin which presents its surface $\mathrm{pH}$ slightly acidic, with $\mathrm{pH}$ around 5.0-6.0(27,40). Any modification in the skin $\mathrm{pH}$ could lead to allergies and other skin conditions $(27,40,41)$. Therefore, the formulation prepared in this work is a good candidate for a skin moisturiser. quando comparadas com os locais de controle da pele (sem aplicação do produto). A incorporação de emolientes a partir de óleos vegetais como componentes tópicos, pode atuar fornecendo teor de lipídeos, e assim, proteção à matriz da pele. Além disso, esses lipídeos são capazes de ajudar no tratamento de algumas doenças de pele, tais como psoríase e dermatite atópica, causada por função de barreira anormal da pele (39).

A adição de Hidraskin ${ }^{\circledR}$ em F4 não pareceu melhorar a hidratação da pele, enquanto que F3 foi preparado apenas com BBL e apresentou o mesmo efeito hidratante sobre a pele. Pode-se sugerir que, uma vez que a formulação base escolhida para este estudo apresentou agentes condicionantes da pele, emolientes e umectantes (por exemplo, álcool cetoestearílico etoxilato, monoestearato de glicerila e glicerina), F6 apresentou um potencial de hidratação mesmo sem conter Hidraskin ${ }^{\circledR}$ ou BBL.

Em relação ao pH da pele, os resultados obtidos (Figura 5 ) estão de acordo com os achados de Wagner e colaboradores (27), nos quais os pesquisadores verificaram que as formulações com $\mathrm{pH}$ de 5,0 a 7,0 são compatíveis com a pele, que apresenta $\mathrm{pH}$ superficial ligeiramente ácido, com pH em torno de 5,0-6,0 $(27,40)$. Qualquer alteração no $\mathrm{pH}$ da pele pode levar a alergias e outras condições da pele $(27,40,41)$. Portanto, a formulação preparada neste trabalho é um bom candidato para um hidratante de pele.

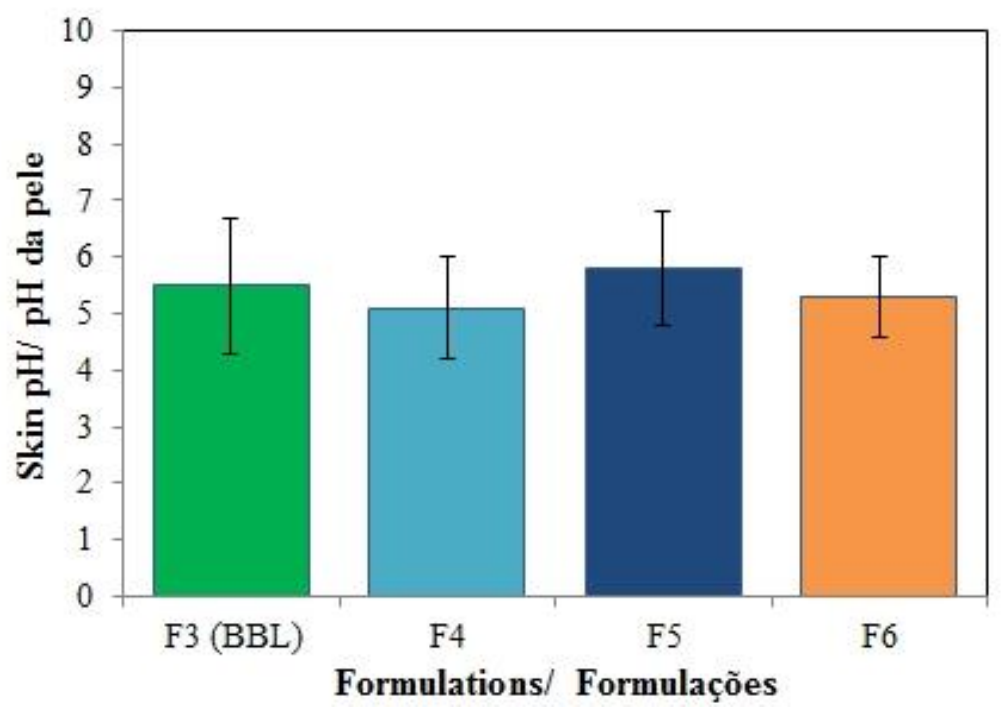

Figure 5/ Figura 5 - Results of skin $\mathrm{pH}$ after the application of F3 (BBL), F4, F5 and F6

Resultados do pH da pele após a aplicação de F3 (BBL), F4, F5 e 


\section{Conclusions}

Babassu oily extracts were obtained from the species $O$. phalerata and used to develop cosmetic formulations in the form of $\mathrm{O} / \mathrm{W}$ emulsions at the concentration of $10 \%$ by weight. These formulations were evaluated concerning their physicochemical properties up to 30 days through stability assays. During the stability assays, the emulsions presented constant viscosity, density, droplets size distribution and $\mathrm{pH}$ compatible with skin $\mathrm{pH}$. Furthermore, these formulations did not present creaming process or phase separation, being considered stable. The main important study of this work was the in vivo efficacy assay, performed by cutaneous biometry, where skin hydration and $\mathrm{pH}$ were evaluated. The results showed an enhancement in skin hydration for the Babassu oily extract from Lowlands region (BBL). This property could be related to the presence of high amounts of lauric acid in BBL which explains its high moisturising potential. No changes in the skin $\mathrm{pH}$ of the volunteers were observed. It could be suggested that formulations containing BBL are promising candidates for cosmetic moisturisers due to the moisturising effect on the skin without disturbing its natural $\mathrm{pH}$.

\section{Acknowledgments}

We would like to thank the Fundação de Amparo à Pesquisa e ao Desenvolvimento Científico e Tecnológico do Maranhão (FAPEMA) and the Rede Amazônica de Pesquisa e Desenvolvimento de Biocosméticos (REDEBIO) for funding.

\section{Conflict of Interests}

The authors declare that there are no financial and/or personal relationships that could be viewed as presenting a potential conflict of interests.

\section{Conclusões}

Os extratos oleosos de Babaçu foram obtidos da espécie O. phalerata e utilizados para desenvolver formulações cosméticas na forma de emulsões $\mathrm{O} / \mathrm{A}$ na concentração de $10 \%$ em peso. Estas formulações foram avaliadas quanto às suas propriedades físico-químicas até 30 dias através de ensaios de estabilidade. Durante os ensaios de estabilidade, as emulsões apresentaram viscosidade constante, densidade, distribuição de tamanho das gotículas e pH compatível com o pH da pele. Além disso, estas formulações não apresentaram processo de cremeação ou separação de fases, sendo consideradas estáveis. O principal estudo deste trabalho foi o ensaio de eficácia in vivo, realizado por biometria cutânea, onde a hidratação da pele e o $\mathrm{pH}$ foram avaliados. Os resultados mostraram um aumento na hidratação da pele para o extrato oleoso de Babaçu da região da Baixada Maranhense (BBL). Esta propriedade pode estar relacionada com a presença de grandes quantidades de ácido láurico no BBL, o que explica seu elevado potencial hidratante. Não foram observadas alterações no $\mathrm{pH}$ da pele dos voluntários. Pode-se sugerir que as formulações contendo BBL são candidatos promissores para hidratantes cosméticos devido ao efeito hidratante sobre a pele sem perturbar seu $\mathrm{pH}$ natural.

\section{Agradecimentos}

Gostaríamos de agradecer à Fundação de Amparo à Pesquisa e ao Desenvolvimento Científico e Tecnológico do Maranhão (FAPEMA) e à Rede Amazônica de Pesquisa e Desenvolvimento de Biocosméticos (REDEBIO).

\section{Conflito de Interesses}

Os autores declaram não existir qualquer relação pessoal ou financeira que possa ser entendida como representando um potencial conflito de interesses. 


\section{References/ Referências}

[1] Badea G, Lacatusu I, Badea N, Ott C, Meghea A. Use of various vegetable oils in designing photoprotective nanostructured formulations for UV protection and antioxidant activity. Ind Crop Prod 2015; 67: 18-24.

[2] Sousa VP, Crean J, Borges VRA, Rodrigues CR, Tajber L, Boylan F, Cabral LM. Nanostructured systems containing babassu (Orbignya speciosa) oil as a potential alternative therapy for benign prostatic hyperplasia. Int J Nanomedicine 2013; 8: 3129-3139.

[3] Rodrigues ECR, Ferreira AM, Vilhena JCE, Almeida FB, Cruz RAS, Rodríguez AJR, Florentino AC, Carvalho JCT, Fernandes CP. Development of Babassu oil based nanoemulsions. Lat Am J Pharm 2015; 34: 338-343.

[4] Bajerski L, Michels LR, Colomé LM, Bender EA, Freddo RJ, Bruxel F, Haas SE. The use of Brazilian vegetable oils in nanoemulsions: an update on preparation and biological applications. Braz J Pharm Sci 2016; 52: 347-363.

[5] Barbosa MCL, Bouskela E, Cyrino FZGA, Azevedo APS, Costa MCP, Souza MGC, Santos DS, Barbosa FL, Guerra LFA, Nascimento MDSB. Effects of babassu nut oil on ischemia/reperfusion-induced leukocyte adhesion and macromolecular leakage in the microcirculation: observation in the hamster cheek pouch. Lipids Health Dis 2012; 11: 158-163.

[6] Gumiero VC, Filho PAR. Babassu nanoemulsions have physical and chemical stability. J Disp Sci Technol 2012; 33: 1569-1573.

[7] Santos DS, Silva IG, Araújo BQ, Lopes-Júnior CA, Monção NBN, Citó AMGL, Souza MHSL, Nascimento MDSB, Costa MCP. Extraction and evaluation of fatty acid compositon of Orbignya phalerata martius oils (Arecaceae) from Maranhão State, Brazil. J Braz Chem Soc 2013; 24 : 355-362.

[8] Lima CG, Pianovski AR, Vilela AFG, Silva KK, Carvalho VFM, De Musis CR, Machado SRP, Ferrari M. O/W/O Multiple emulsions containing Amazon oil: Babassu Oil (Orbignya oleifera). J Disper Sci Technol 2010; 31: 622-626.

[9] Martins NLP, Malafaia O, Ribas-Filho JM, Heibel M, Baldez RN, Vasconcelos PRL, Moreira H, Mazza M, Nassif PAN, Masmoudi H, Le-Dréau Y, Piccerelle P, Kister J. The evaluation of cosmetic and pharmaceutical emulsions aging process using classical techniques and a new method: FTIR. Int J Pharm 2005; 289: 117-131.

[10] Amorim E, Matias JE, Coelho JC, Campos AC, Stahlke-Júnior HJ, Timi JR, Rocha LC, Moreira AT, Rispoli DZ, Ferreira LM. Topic use of aqueous extract of Orbignya phalerata (babassu) in rats: analysis of its healing effect. Acta Cir Bras 2006; 21: 67-76.

[11] Batista CP, Torres OJM, Matias JEF, Moreira ATR, Colman D, Lima JHF, Macri MM, Rauen-Júnior RJ, Ferreira LM, Freitas ACT. Effect of watery extract of Orbignya phalerata (babassu) in the gastric healing in rats: morfologic and tensiometric study. Acta Cir Bras 2006; $21: 26-32$.

[12] Barroqueiro ESB, Barroqueiro FSB, Pinheiro MT, Maciel MCG, Barcellos OS, Silva LA, Lopes AS, Nascimento FRF, Guerra RNM. Evaluation of acute toxicity of babassumesocarp in mice. Braz J Pharmacog 2011; 21: 710-714.

[13] Harry RG. Harry's Cosmeticology. 8th ed. New York: Chemical Publishing Company Inc.; 2000.

[14] Mcclements DJ. Food emulsions: principles, practice and techniques. 2nd ed. Ohio: CRC Press.; 2004.

[15]Lobo L, Svereika A. Coalescence during emulsification: 2. Role of small molecule surfactants. J Colloid Interface Sci 2003; 261: 498-507.

[16] Guzey D, Mcclements DJ. Formation, stability and properties of multilayer emulsions for application in the food industry. Adv Colloid Interface Sci 2006; 130: 227-248.

[17] Taylor KMG, Aulton ME. Aulton's Pharmaceutics: The Design and Manufacture of Medicines. 4th ed. London: Churchill Livingstone; 2013.

[18] Karakashev SI, Manevb ED, Tsekov R, Nguyen AV. Effect of ionic surfactants on drainage and equilibrium thickness of emulsion films. J Colloid Interface Sci 2008; 318: 358-364.

[19] Bali V, Ali M, Ali J. Study of surfactant combinations and development of a novel nanoemulsion for minimising variations in bioavailability of ezetimibe. Colloids Surf B Biointerf 2010; 76: 410-420.

[20]Ferreira BS, Almeida CG, Faza LP, Almeida A, Diniz CG, Silva VL, Grazul RM, Hyaric ML. Comparative properties of amazonian oils obtained by different extraction methods. Molecules 2011; 16: 5875-5885.

[21] Smith EW, Maibach HI. Percutaneous Penetration Enhancers. 2nd ed. London: CRC Press.; 2005.

[22] Dal'Belo SE, Gaspar LR, Maia-Campos PM. Moisturizing effect of cosmetic formulations containing Aloe vera extract in different concentrations assessed by skin bioengineering techniques. Skin Res Technol 2006; 12: 241-246.

[23] Kopecký F. Physics for Students of Pharmacy I. Bratislava, UK (in Slovak): United Kingdom; 1999.

[24] Relkin P, Yung JM, Kalnin D, Ollivon M. Structural behaviour of lipid droplets in protein-stabilized nano-emulsions and stability of $\alpha$-tocopherol. Food Biophys 2008; 3: 163-168.

[25] Chanamai R, Herrmann N, Mcclements DJ. Ultrasonic spectroscopy study of flocculation and shear-induced floc disruption in oil-in-water emulsions. J Colloid Interface Sci 1998; 204: 268-276.

[26] Tadros T. Application of rheology for assessment and prediction of the long-term physical stability of emulsions. Adv Colloid Interface Sci 2004; 109: 227-258.

[27] Wagner H, Kostka KH, Lehr CM, Schaefer UF. pH profiles in human skin: influence of two in vitro test systems for drug delivery testing. Eur J Pharm Biopharm 2003; 55: 57-65.

[28] Segger D, Abmus U, Brock M, Erasmy J, Finkel P, Fitzner A, Heuss H, Kortemeier U, Munke S, Rheinländer T, Schmidt-Lewerkühne H, Schneider W, Weser G. Multicenter study on measurement of the natural pH of the skin surface. Int J CosmetSci 2008; 30: 75-76.

[29] Knor T, Meholjic-Fetahovic A, Mehmedagic A. Stratum corneum hydration and skin surface $\mathrm{pH}$ in patients with atopic dermatitis. Acta Dermatovenerol Croat 2011; 19: 242-247.

[30] Robins MM, Watson AD, Wilde PJ. Emulsions-creaming and rheology. Curr Opin Colloid Interface Sci 2002; 7: 419-425.

[31] Merryweather LM. Dictionary of Food Science and Technology. 2nd ed. Oxford: Blackwell Publishing, 2005.

[32] Morais GG, Santos ODH, Masson DS, Oliveira WP, Rocha-Filho PA. Development of O/W emulsions with annato oil (Bixaorellana) containing liquid crystal. J Disper Sci Technol 2005; 26: 591-596.

[33] Shin SH, Cho JW, Kim SH. Shear thinning behavior of calcium silicate-based mold fluxes at 1623 K. J Am Ceram Soc 2014; 97: $3263-3269$.

[34] Chassenieux C, Nicolai T, Benyahia L. Rheology of associative polymer solutions. Curr Opin Colloid Interface Sci 2011; 16: 18-26.

[35] Forster AH, Herrington TM. Rheology of siloxane-stabilized water in silicone emulsions. Int J Cosmet Sci 1997; 19: 173-91.

[36] Vasiljevic D, Vuleta G, Primorac M. The characterization of the semi-solid W/O/W emulsions with low concentrations of the primary polymeric emulsifer. Int J Cosmet Sci 2005; 27: 81-87.

[37] Sousa VP, Crean J, Borges VRA, Rodrigues CR, Tajber L, Boylan F, Cabral LM. Nanostructured systems containing babassu (Orbignya speciosa) oil as a potential alternative therapy for benign prostatic hyperplasia. Int J Nanomedicine 2013; 8: 3129-3139.

[38] Keng PS, Basri M, Zakaria MRS, Abdul-Rahman MB, Ariff AB, Abdul-Rahman RNZ, Salleh AB. Newly synthesized palm esters for cosmetics industry. Ind Crop Prod 2009; 29: 37-44.

[39] Raone B, Ravaioli GM, Dika E, Neri I, Gurioli C, Patrizi A. The use of emollients for atopic eczema. Austin J Allergy 2015; 2: 1018-1029.

[40] Yenilmez E, Basaran E, Yazan Y. Release characteristics of vitamin E incorporated chitosan microspheres and in vitro-in vivo evaluation for topical application. Carbohyd Polym 2011; 84: 807-811.

[41] Glampedaki P, Dutschk V. Stability studies of cosmetic emulsions prepared from natural products such as wine, grape seed oil and mastic resin. Colloids Surf A Physicochem Eng Asp 2014; 460: 306-311. 